\title{
Isolation and characterization of zinc-binding proteins of canine seminal plasma
}

\author{
M. Mogielnicka-Brzozowska, L. Fraser, J. Czarzasta, W. Kordan \\ Faculty of Animal Bioengineering, Department of Animal Biochemistry and Biotechnology, \\ University of Warmia and Mazury in Olsztyn, Oczapowskiego 5, 10-718 Olsztyn, Poland
}

\begin{abstract}
Zinc-binding proteins from seminal plasma (ZnBPs) originate in the secretions of different accessory sex glands and are implicated in key events associated with sperm-egg fertilization processes. This study describes the isolation and characterization of the ZnBPs of canine seminal plasma. Ejaculates were collected from three crossbred dogs for a 2-week period. The ZnBPs as well as non zinc-binding proteins (nZnBPs) were isolated by zinc-dependent affinity chromatography. The isolated fractions were subjected to native gel electrophoresis (one-dimensional polyacryamide gel electrophoresis, PAGE) and sodium dodecyl sulphate polyacryamide gel electrophoresis (SDS-PAGE), using denaturing and reducing conditions. Zinc-elution profile using affinity chromatography displayed two protein fractions represented by the nZnBPs and ZnBPs, respectively. Using native gel electrophoresis, it was found that both the nZnBPs and ZnBPs occurred in their native state as aggregates, ranging from 140 to $669 \mathrm{kDa}$. The nZnBPs were disaggregated into 8 protein bands, with molecular weights ranging from 10.7 to $79.7 \mathrm{kDa}$, following SDS-PAGE analysis. By contrast, SDS-PAGE analysis of the ZnBPs revealed 13 protein bands, with molecular weights ranging from 11.6 to $152.3 \mathrm{kDa}$. Densitometric analysis showed that $46-48 \%$ of nZnBPs could be accounted by protein fractions with molecular weights of 10.7 and $14.2 \mathrm{kDa}$. Also, 2 protein fractions with molecular weights of 11.6 and $14.3 \mathrm{kDa}$, were predominant in ZnBPs, accounting for approximately 28-30\% of the total proteins. These results demonstrate the zinc-binding capacity of proteins secreted by the canine prostate. The findings of this study indicate that ZnBPs of canine seminal plasma comprise several protein fractions, which might be implicated in the reproductive processes in the dog.
\end{abstract}

Key words: dogs, seminal plasma, electrophoresis, zinc-binding proteins

\section{Introduction}

Seminal plasma, a complex mixture of secretions originating from the testis, epididymis and accessory sex glands, modulates the fertilizing ability of spermatozoa (Russell et al. 1984, Strzeżek et al. 2005). Increasing evidence shows that some of the seminal plasma proteins are bound to the sperm surface dur- ing ejaculation and thus forming protein-coating layers (Jonáková et al. 2007). As regards the dog, most of the seminal plasma components, which are implicated in the sperm function, originate in the prostatic secretion (Nothling et al. 1993, Sirivaidyapong et al. 2001, De Souza et al. 2006, 2007, Strzeżek and Fraser 2009, Cheema et al. 2011). Electrophoretic analysis has shown that proteins, secreted 
by the canine prostate, are different from the accessory sex gland secretions of other animal species, in terms of both quantity and quality (Dubiel 1974, Dubé et al. 1985).

Accumulating evidence has been shown that zinc ions, secreted by the prostate and vesicular glands, bind to different proteins ligands, which are implicated in sperm-egg fertilization processes in the female reproductive tract (Boursnell et al. 1975, Arver 1982, Hołody and Strzeżek 1999, Siciliano et al. 2000, Mogielnicka-Brzozowska et al. 2011). Zinc-binding proteins (ZnBPs) have been identified in the seminal plasma of human (Arver 1982, Arver and Eliasson 1982, Siciliano et al. 2000) and boar (Boursnell et al. 1975, Strzeżek et al. 1987, Hołody and Strzeżek 1999, Mogielnicka-Brzozowska et al. 2011). Evidence has been shown that most of the zinc in human and canine seminal plasma originates in the prostate (Johnson et al. 1969, Lindholmer and Glaumann 1972). Zinc is involved in normal testicular development, spermatogenesis, and sperm function (Henkel et al. 2003). It has been demonstrated that approximately $93 \%$ of the zinc is located in the flagellum of the ejaculated spermatozoa (Henkel et al. 1999), while the remaining 7\% zinc is located in the sperm head, contributing to the stability of the quaternary structure of the sperm nuclear chromatin (Bjöndahl and Kvist 1990, Kvist et al. 1990).

To date, ZnBPs of canine seminal plasma have not been investigated although the presence of heparin-binding proteins have been reported (De Souza et al. 2006). The aim of this study was to identify and characterize the ZnBPs of canine seminal plasma, using zinc-dependent affinity chromatography and electrophoretic analysis. Also, the potential role of the $\mathrm{ZnBPs}$ in the reproductive processes in the dog has been addressed.

\section{Materials and Methods}

\section{Animals and semen collections}

Three healthy crossbred dogs (aged 3 to 5 years) of unknown fertility were used in this study. Ejaculates $(\mathrm{n}=6)$ were collected from each dog in November for a 2-week period, using digital manipulation. The animals were kept in individual cages with access to water (at libitum) and fed with commercial canine food. All experiments were carried out in accordance with the guidelines set out by the Local Ethics Committee for Experimentation with Animals.

Each ejaculate was centrifuged $(1000 \times \mathrm{g}, 15 \mathrm{~min}$ at room temperature) to remove the suspended spermatozoa. The recovered seminal plasma was further centrifuged $(10000 \times \mathrm{g}, 10 \mathrm{~min}$ at room temperature $)$. The resultant supernatant was dialyzed against deionized $\mathrm{H}_{2} \mathrm{O}$ for $24 \mathrm{~h}$ at room temperature and stored at $-80^{\circ} \mathrm{C}$, until required for further analysis.

All chemical reagents were of the highest purity grade available and were purchased from Sigma Aldrich (St. Louis, MO, USA), unless otherwise stated.

\section{Protein determination}

Total protein content was measured in the fresh seminal plasma and in the recovered protein fractions obtained by zinc-dependent affinity chromatography, according to Lowry et al. (1951), using bovine serum albumin (BSA, Serum and Vaccine Production, Cracow, Poland) as a standard.

\section{Zinc-dependent affinity chromatography}

Zinc-dependent affinity chromatography was used to isolate the non zinc-binding (nZnBPs) and zinc-binding proteins (ZnBPs) of pooled seminal plasma of 3 dogs, as described previously (Hołody and Strzeżek 1999, Mogielnicka-Brzozowska et al. 2011), with some modifications. Chelating Sepharose Fast Flow gel, packed in 10-ml column, HR 10/10 (Amersham Biosciences), was equilibrated with $0.5 \mathrm{M} \mathrm{NaCl}$ in $0.5 \mathrm{M}$ Tris- $\mathrm{HCl}$ buffer ( $\mathrm{pH} 8.0)$ and saturated with an aqueous solution of $2 \% \mathrm{ZnCl}_{2}$. After the column had been washed twice with the equilibration buffer, aliquots $(2 \mathrm{ml})$ of diluted seminal plasma with equilibration buffer (1:1) were loaded. The column was washed to remove unabsorbed proteins - non zinc-binding proteins (nZnBPs). The absorbed zinc-binding proteins ( $\mathrm{ZnBPs}$ ) were eluted with a buffer comprising $0.5 \mathrm{M}$ Tris-HCl buffer $(\mathrm{pH} 7.5)$ and

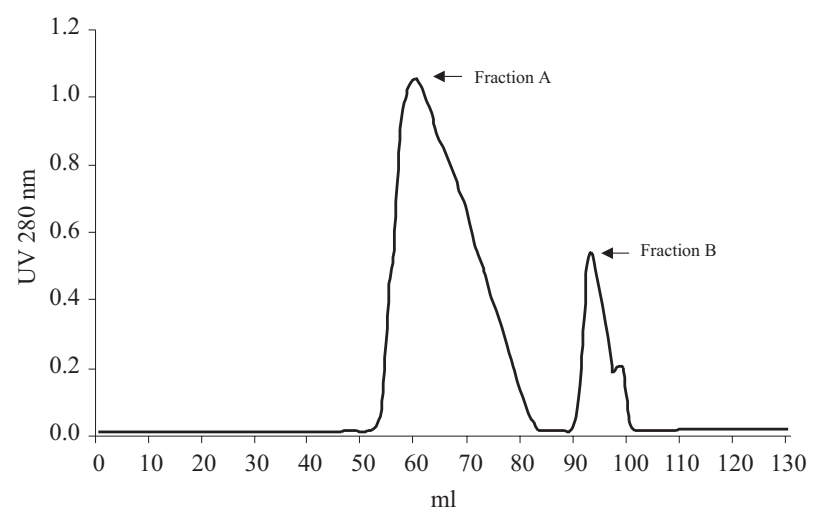

Fig. 1. Graphic image plotted by UNICORN Control System software (Amersham Biosciences, Uppsala, Sweden) of (A) non-zinc-binding (nZnBPs) and (B) zinc-binding proteins (ZnBPs) of canine seminal plasma separated by zinc-dependent affinity chromatography. 
$0.1 \mathrm{M}$ imidazole. Both the nZnBPs and ZnBPs fractions were eluted in 5-ml fractions. The column was regenerated with $0.5 \mathrm{M}$ Tris-acetate, $0.5 \mathrm{M} \mathrm{NaCl}$ and $0.5 \mathrm{M}$ EDTA ( $\mathrm{pH}$ 7.5). The data and graphics of the isolated $\mathrm{nZnBP}$ and $\mathrm{ZnBP}$ fractions were plotted by specialized software (UNICORN ${ }^{\mathrm{TM}}$, Amersham Biosciences, Uppsala, Sweden). Protein-containing fractions were collected and pooled (Fig. 1). The recovered nZnBP (Fraction A) and ZnBP (Fraction B) fractions were dialyzed against deionized $\mathrm{H}_{2} \mathrm{O}$ for $24 \mathrm{~h}$ at room temperature. The selected proteins fractions were analyzed for protein content and stored at $-80^{\circ} \mathrm{C}$ until further analysis.

\section{Electrophoretic characterization of ZnBPs}

One dimensional polyacrylamide gel electrophoresis, under non-denaturing (PAGE), and denaturing and reducing (SDS-PAGE) conditions, were performed according to the method of Laemmli (1970).

For PAGE analysis, aliquot of protein samples were diluted (1:1) with 2-fold concentrated buffer containing $0.34 \mathrm{M}$ Tris- $\mathrm{HCl}, 20 \%$ glycerol, $2 \%$ bromophenol blue ( $\mathrm{pH}$ 6.8). Native electrophoresis was conducted in $6 \%$ polyacrylamide gel slabs. Electrophoresis was performed at constant voltage $(120 \mathrm{~V})$ in a buffer $(0.5 \mathrm{M}$ Tris, $0.25 \mathrm{M}$ glycine, $\mathrm{pH}$ 8.3). After electrophoresis the gel was stained with Coomassie Brilliant Blue. Molecular mass was estimated using the High Molecular Weight Calibration Kit for Native Electrophoresis (Amersham Biosciences).

Briefly for SDS-PAGE analysis, aliquots of protein samples were diluted at ratio (1:1) with 2-fold concentrated lysis buffer $(0.34 \mathrm{M}$ Tris- $\mathrm{HCl}, 10 \%$ SDS, $20 \%$ glycerol, $2 \% \beta$-mercaptoethanol, $2 \%$ bromophenol blue, $\mathrm{pH}$ 6.8) and heated for $5 \mathrm{~min}$ at $95^{\circ} \mathrm{C}$. Before loading, the samples were centrifuged at $(10000 \times \mathrm{g}$ for $5 \mathrm{~min}$ at room temperature) and the supernatant was used for electrophoretic analysis. Different protein concentrations $(35,17$ and $4 \mu \mathrm{g}$ ) were loaded into the gel wells to obtain optimal resolution of the analyzed protein fractions. Electrophoresis was performed in $12 \%$ polyacrylamide gel in a buffer containing $0.5 \mathrm{M}$ Tris, $0.25 \mathrm{M}$ glycine and $0.5 \%$ SDS (pH 8.3) at a constant voltage $(120 \mathrm{~V})$. Following electrophoresis, the gel was stained with Coomassie Brilliant Blue and the molecular mass of the protein bands were determined using the Low Molecular Weight Standards (Amersham Biosciences). Densitometric analysis was performed to quantify the protein bands, using the MultiAnalyst software (BioRad, Warsaw, Poland).

\section{Results}

The overall mean total protein content in the pooled seminal plasma of the 3 dogs was $29.9 \pm 1.8$ $\mathrm{mg} / \mathrm{ml}$ (mean $\pm \mathrm{SD}$ ).

Figure 1 shows the graphic image plotted on the zinc-dependent affinity chromatography of eluted canine seminal plasma proteins. The zinc-elution profile showed 2 different peaks of the isolated seminal plasma protein fractions; the higher curve was represented by nZnBPs (Fraction A), whereas the lower curve contained the ZnBPs (Fraction B). Image software analysis showed that the ZnBPs accounted for 4 to $10 \%$ of the total seminal plasma proteins.

Electrophoresis analysis (PAGE) of the peak-containing the nZnBPs and ZnBPs of canine seminal plasma showed that these proteins occurred in their native state, as high molecular weight aggregates, ranging from 140 to $669 \mathrm{kDa}$ (Fig. 2A for the nZnBPs and Fig. 2B for the ZnBPs).

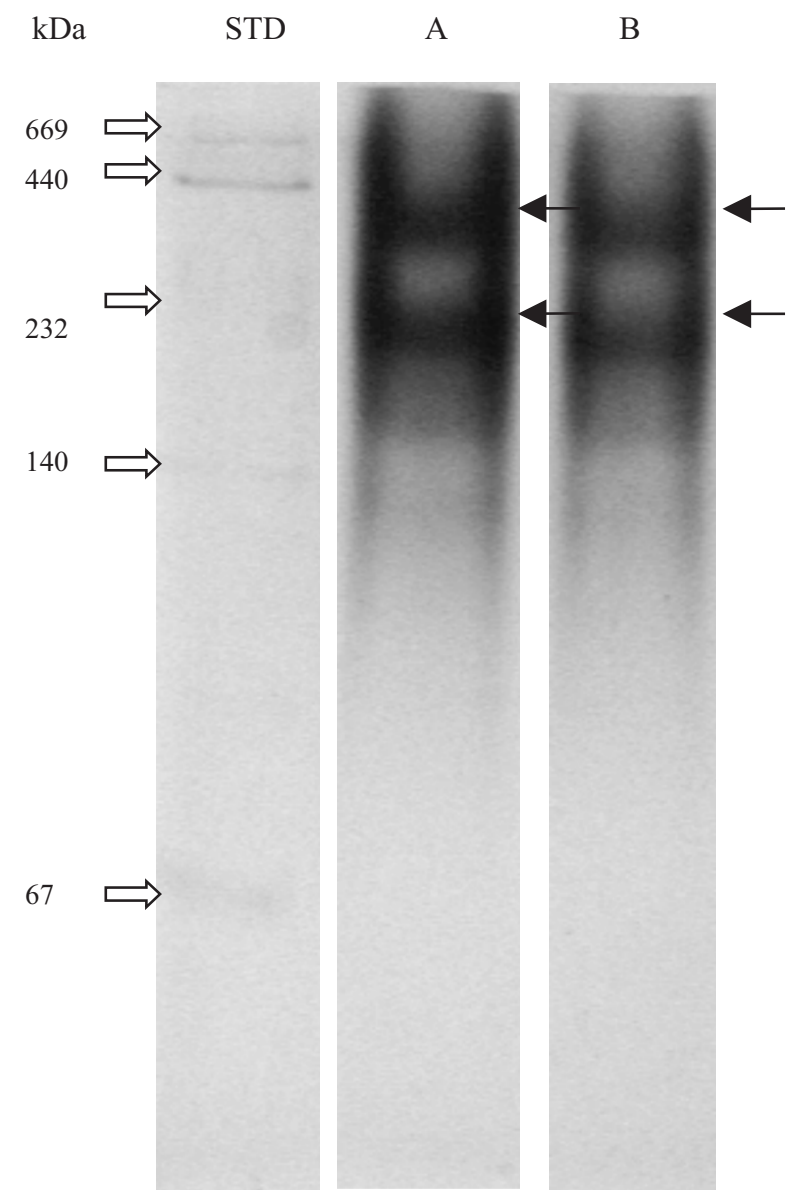

Fig. 2. Polyacrylamide gel electrophoresis (PAGE) of isolated (A) non-zinc-binding (nZnBPs) and (B) zinc-binding proteins $(\mathrm{ZnBPs})$ of canine seminal plasma in their native states. Each lane consists of $122 \mu \mathrm{g}$ of protein. STD - High Molecular Weight Calibration Kit for Native Electrophoresis (Amersham Biosciences). 
A

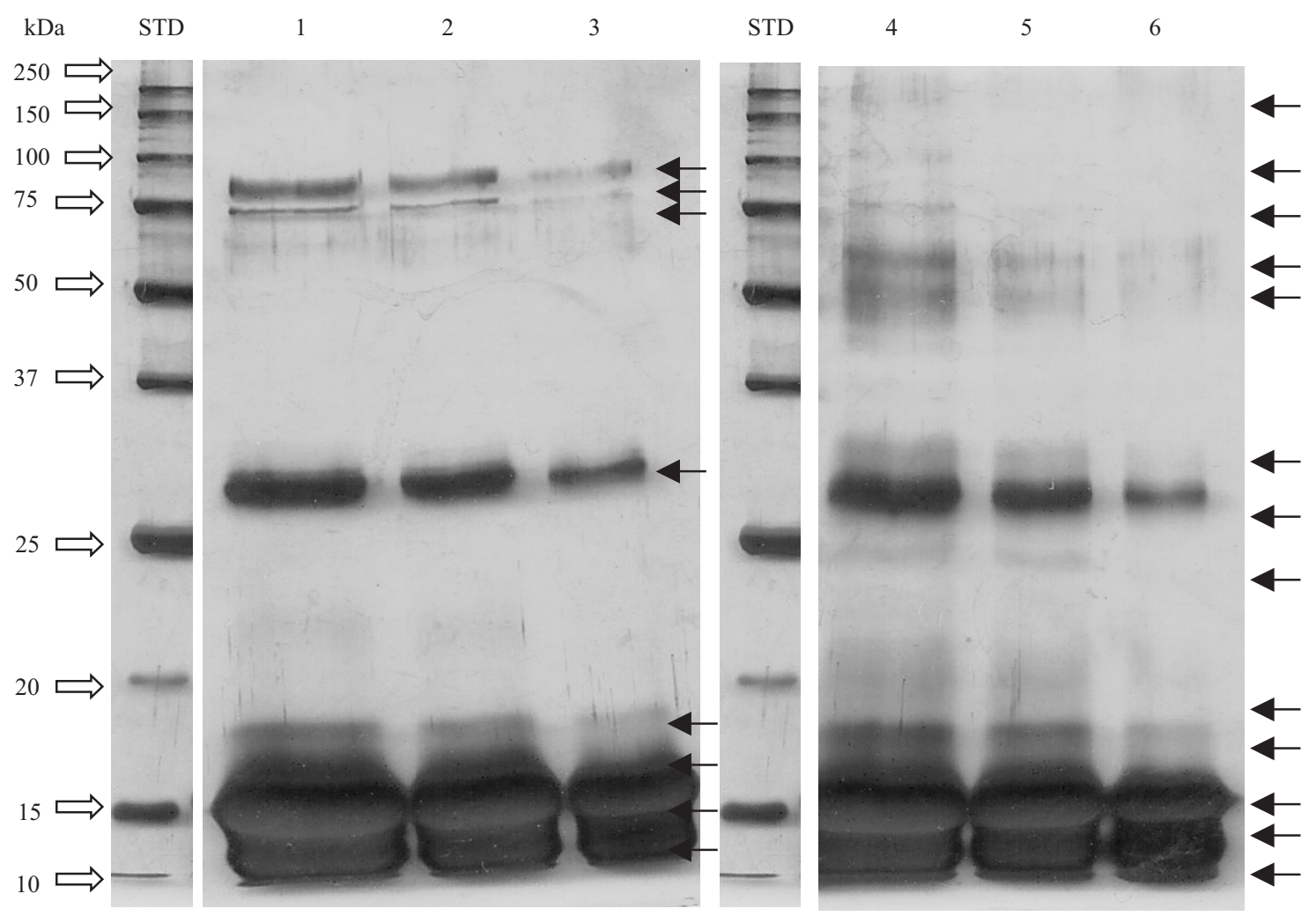

Fig. 3. Sodium dodecyl sulphate polyacrylamide gel electrophoresis (SDS-PAGE) of isolated (A) non-zinc-binding (nZnBPs) and (B) zinc-binding proteins (ZnBPs) of canine seminal plasma. Different amounts of protein were loaded into the gel wells to obtain optimal resolution of the protein bands. Lanes 1 and 4: $35 \mu \mathrm{g}$. Lanes 2 and 5: $17 \mu \mathrm{g}$. Lanes 3 and 6: $4 \mu \mathrm{g}$. STD - Precision Plus Protein Standard (BioRad).

Under denaturing and reducing conditions (SDS-PAGE), a total of 21 protein bands were identified in both the nZnBPs and ZnBPs of the pooled seminal plasma (Fig. 3). Furthermore, SDS-PAGE analysis revealed that the nZnBPs were disaggregated into 8 protein bands, with molecular weights of 10.7, 14.2, 16.5, 17.8, 27.6, 63.4, 69.3 and $79.7 \mathrm{kDa}$ (Fig. 3A). By contrast, SDS-PAGE analysis of the eluted ZnBPs revealed 13 protein bands, with molecular weights of 11.6, 14.3, 16.2, 18.8, 20.1, 24.3, 27.6, 29.8, 50.1, 60.2, 70.2, 111.4 and $152.3 \mathrm{kDa}$ (Fig. 3B). Densitometric analysis of the SDS-PAGE gel showed that 2 protein fractions, with molecular weights of 10.7 and $14.2 \mathrm{kDa}$, accounted for approximately $46-48 \%$ of the total proteins detected in the nZnBPs. On the other hand, protein fractions, with molecular weights of 11.6 and $14.3 \mathrm{kDa}$, were the predominant in the ZnBPs, accounting for approximately $28-30 \%$ of the total proteins.

\section{Discussion}

To the best of our knowledge, this study has isolated and characterized, for the first time, the zinc-ligandprotein complexes of canine seminal plasma. Our findings have confirmed that zinc of canine seminal plasma has a strong affinity for protein ligands with different molecular weights. Moreover, it was shown that zinc could bind to high, intermediate and low molecular weight protein ligands, originating in the vesicular and prostatic secretions in human seminal plasma (Arver 1982, Arver and Eliasson 1982, Siciliano et al. 2000). These authors have postulated that a redistribution of zinc takes place at ejaculation. In the present study, PAGE analysis of the $\mathrm{ZnBPs}$ of canine seminal plasma detected aggregates in their native state. Since most of the secretions of canine seminal plasma are derived from the prostate (Dube et al. 1985, Nothling et al. 1993), it can be suggested that the bulk of the proteins showing zinc-binding capacity originate mainly in the prostate. Also, studies in our laboratory have confirmed that zinc of boar seminal plasma can interact with protein ligands, high-molecular weight components, in their native state at ejaculation (Strzeżek et al. 1987, Hołody and Strzeżek 1999, Mogielnicka-Brzozowska et al. 2011).

Evidence has been shown that the interactions of zinc of the seminal plasma with high-molecular 
weight ligands of the seminal plasma can affect the biological property of zinc, and consequently sperm function (Björndahl and Kvist 1990, Kvist et al. 1990). According to Björndahl and Kvist (1990), protein ligands of the seminal plasma bind the free and loosely bound zinc at ejaculation, reducing the zinc fraction available for the sperm cells. Moreover, high abundance of the protein ligands could deplete zinc from spermatozoa, resulting in impaired sperm function (Kvist et al. 1990). In the present study, SDS-PAGE analysis showed that the ZnBPs of canine seminal plasma disaggregated into several protein fractions with various molecular weights, which can have various effects on sperm function. These results have been corroborated by findings of other authors, when ZnBPs of human and boar seminal plasma were analyzed by SDS-PAGE (Arver 1982, Arver and Eliasson 1982, Hołody and Strzeżek 1999, Jonhkovh et al. 2007).

In recent years, several proteins, which have been isolated and characterized in canine seminal plasma, have been shown to be associated with fertility (Dubiel 1974, De Souza et al. 2007, Cheema et al. 2011). Several authors have reported that components of prostatic secretion can have various effects on sperm function following semen storage or cryopreservation (Nothling et al. 1993, Sirivaidyapong et al. 2001, Strzeżek and Fraser 2009). Moreover, significant correlations of two seminal plasma proteins (67 and $58.6 \mathrm{kDa}$ ) were found with sperm quality characteristics, and suggested to be valuable markers for fertility (De Souza et al. 2007). It was demonstrated that the concentrations of 4 protein fractions $(14,24,70$ and $82 \mathrm{kDa}$ ) of canine seminal plasma correlated with semen quality parameters (Cheema et al. 2011). Recently, it has been reported that proteins of intermediate- and low-molecular weights (ranging from 24 to $42 \mathrm{kDa}$ ) account for 61.3 to $74.3 \%$ of the total protein concentration in the seminal plasma of dogs (Cheema et al. 2011). Several authors reported that $12-14 \mathrm{kDa}$ and $15 \mathrm{kDa}$ protein fractions were enzyme arginine esterase, which could account for about $90 \%$ of the total proteins secreted by the prostate and $30 \%$ of the seminal plasma proteins in the dog (Isaacs and Coffey 1984, Dube et al. 1985, De Souza et al. 2007). In our recent study, we have shown that the ZnBPs of boar seminal plasma improved sperm motility and acrosome integrity of preserved spermatozoa, presumably by coating the sperm surface (Mogielnicka-Brzozowska et al. 2011). Similar findings have been reported by other studies (Nothling et al. 1993, Sirivaidyapong et al. 2001, Strzeżek and Fraser 2009), indicating that the prostatic secretion possesses sperm-coating sub- stances, which protect sperm function during semen preservation. Our results have shown that ZnBPs comprise $4-10 \%$ of the total seminal plasma proteins, and under denaturing and reducing conditions, disaggregated into 13 protein fractions, with molecular weights ranging from 11.6 to $152.3 \mathrm{kDa}$. It is possible that the ZnBPs of canine seminal plasma, particularly the predominant low-molecular weights protein components (11.6 and $14.6 \mathrm{kDa})$, might be implicated in key events associated with sperm-egg fertilization processes. This assumption has been confirmed by findings of several authors (Töpfer-Petersen 1999, Strzeżek et al. 2005, De Souza et al. 2006, Jonáková et al. 2007), indicating that seminal plasma proteins bound on the sperm surface are implicated in sperm-egg fertilization processes, including sperm capacitation and egg recognition, in the female reproductive tract. On-going studies in our laboratory have shown that ZnBPs comprise the enzyme arginine esterase subunits and have beneficial effects on sperm plasma membrane integrity during liquid storage of canine semen (unpublished data). Besides the dog, seminal plasma proteins have been suggested to be good candidates for markers of fertility in the horse, bull and boar (Killian et al. 1993, Brandon et al. 1999, Nowak et al. 2010).

In summary, the findings of this study indicate that the ZnBPs of canine seminal plasma comprise several protein fractions, which might be implicated in key events associated with the reproductive processes in the dog. Further studies on the characterization of the ZnBPs of canine seminal plasma and their binding property are currently underway in our laboratory. It is envisaged that the ZnBPs will be a valuable marker for canine sperm fertility and will be useful in the improvement of the reproductive technologies in the dog.

\section{Acknowledgements}

This study was supported by funds from the University of Warmia and Mazury in Olsztyn (No. 0103.0803). The authors would like to thank Dr Rafał Strzeżek for kindly supplying the biological materials.

\section{References}

Arver S (1982) Zinc and zinc ligands in human seminal plasma. III. The principal low molecular weight zinc ligands in prostatic secretion and seminal plasma. Acta Physiol Scand 116: 67-73.

Arver S, Eliasson R (1982) Zinc and zinc ligands in human seminal plasma. II. Contribution by ligands of different 
origin to the zinc binding properties of human seminal plasma Acta Physiol Scand 115: 217-224.

Bjorndahl L, Kvist U (1990) Influence of seminal vesicular fluid on the zinc content of human sperm chromatin. Int J Androl 13: 232-237.

Boursnell JC, Noble EA, Andrews MG (1975) Boar seminal zinc-precipitable protein and the haemagglutinin. J Reprod Fertil 45: 415-420.

Brandon CI, Heusner GL, Caudle AB, Fayrer-Hosken RA (1999) Two-dimensional polyacrylamide gel electrophoresis of equine seminal plasma proteins and their http://www.ncbi.nlm.nih.gov/pubmed/10735126 correlation with fertility 52: 863-873.

Cheema RS, Bhakri G, Gandotra VK, Dhanju CK (2011) Characterization of mongrel dog seminal plasma proteins and their correlation with semen characteristics. J Reprod Stem Cell Biotechnol 2: 55-63.

De Souza F, Martins MI, dos Santos Fernandes CE, Ribolla PE, Lopes MD (2006) Heparin-binding proteins of canine seminal plasma. Theriogenology 66: 1606-1609.

De Souza FF, Barreto CS, Lopes MD (2007) Characteristics of seminal plasma proteins and their correlation with canine semen analysis. Theriogenology 68: 100-106.

Dube JY, Frenette G, Chapdelaine P, Paquin R, Tremblay RR (1985) Biochemical characteristics of the proteins secreted by dog prostate, a review. Exp Biol 43: 149-159.

Dubiel A (1974) Electrophoretic studies of dog semen plasma in both fertile and sterile dogs. Polskie Archiwum Weterynaryjne 17: 699-706.

Henkel R, Baldauf C, Schill WB (2003) Resorption of the element zinc from spermatozoa by the epididymal epithelium. Reprod Domest Anim 38: 97-101

Henkel R, Bittner J, Weber R, Huther F, Miska W (1999) Relevance of zinc in human sperm flagella and its relation to motility. Fertil Steril 71: 1138-1143.

Hołody D, Strzeżek J (1999) Heparin- and $\mathrm{Zn}^{2+}$-binding proteins from boar seminal plasma. Acta Biochim Pol 46: 935-939.

Isaacs WB, Coffey DS, (1984) The predominant protein of canine seminal plasma is an enzyme. J Biol Chem 259: $11520-11526$.

Johnson L, Wikstrom S, Nylander G, (1969) The vehicle for zinc in the prostatic secretion of dogs. Scand $\mathbf{J}$ Urol Nephrol 3: 9-11.

Jonáková V, Mañásková P, Tichá M (2007) Separation, characterization and identification of boar seminal plasma proteins. Chromatogr B 849: 307-314.

Killian GJ, Chapman DA, Rogowski LA (1993) Fertility-associated proteins in Holstein bull seminal plasma. Biol Reprod 49: 1202-1207.
Kvist U, Kjelberg S, Björndahl L, Soufir JC, Arver S (1990) Seminal fluid from men with agenesis of the Wolffian ducts: zinc-binding properties and effects on sperm chromatin stability. Int J Androl 13: 245-252.

Laemmli UK (1970) Cleavage of structural proteins during the assembly of the head of bacteriophage T4. Nature 227: 680-685.

Lindholmer C, Glauman H (1972) Zinc and magnesium in human male reproductive tract. Andrologie 4: 231-237.

Lowry OH, Rosenbrough NJ, Farr AL, Randall RJ (1951) Protein measurement with the Folin phenol reagent. J Biol Chem 193: 265-275.

Mogielnicka-Brzozowska M, Wysocki P, Strzezek J, Kordan W (2011) Zinc-binding proteins from boar seminal plasma - isolation, biochemical characteristics and influence on spermatozoa stored at $4^{\circ} \mathrm{C}$. Acta Biochim Pol 58: 171-177.

Nothling JO, Volkmann DH (1993) Effect of addition of autologous prostatic fluid on the fertility of frozen-thawed dog semen after intravaginal insemination. J Reprod Fertil 47: 329-333.

Novak S, Ruiz-Sanchez A, Dixon WT, Foxcroft GR, Dyck MK (2010) Seminal plasma proteins as potential markers of relative fertility in boars. J Androl 31: 188-200.

Russell LD, Peterson RN, Hunt W, Strack LE (1984) Posttesticular surface modifications and contributions of reproductive tract fluids to the surface polypeptide composition of boar spermatozoa. Biol Reprod 30: 959-978.

Siciliano L, De Stefano C, Petroni MF, Vivacqua A, Rago V, Carpino A (2000) Prostatic origin of a zinc binding high molecular weight protein complex in human seminal plasma. Mol Hum Reprod 6: 215-218.

Sirivaidyapong S, Ursem P, Bevers MM, Colenbrander B (2001) Effect of prostatic fluid on motility, viability and acrosome integrity of chilled and frozen-thawed dog spermatozoa. J Reprod Fertil Suppl 57: 383-386.

Strzeżek R, Fraser L (2009) Characteristics of spermatozoa of whole ejaculate and sperm-rich fraction of dog semen following exposure to media varying in osmolality. Reprod Biol 9: 113-126.

Strzeżek J, Hopfer E, Zaborniak A (1987) Zinc ion dependent protein in boar semen. II. Effects on sperm motility and antibacterial properties. Anim Reprod Sci 13: 133$-142$.

Strzeżek J, Wysocki P, Kordan W, Kuklińska M, Mogielnicka M, Soliwoda D, Fraser L (2005) Proteomics of boar seminal plasma - current studies and possibility of their application in biotechnology of animal reproduction. Reprod Biol 5: 279-290.

Töpfer-Petersen E (1999) Molecules on the sperm's route to fertilization. J Exp Zool 285: 259-266. 